\title{
PENANGANAN PELANGGARAN KODE ETIK ANGGOTA KEPOLISIAN ATAS STATUS PERKAWINAN
}

\author{
Nur Ekowati, Kukuh Sudarmanto, Muhammad Junaidi, Sukimin Sukimin \\ Magister Hukum Universitas Semarang, Semarang \\ institutjunaidi@gmail.com
}

\begin{abstract}
Abstrak
Tujuan penelitian ini adalah untuk mengkaji bagaimana penanganan pelanggaran kode etik anggota kepolisian di wilayah hukum Polda Jawa Tengah atas status perkawinan dan bagaimana penanganan ideal atas reposisi pelanggaran kode etik anggota kepolisian di wilayah hukum Polda Jawa Tengah atas status perkawinannya. UndangUndang Nomor 1 Tahun 1974 yang merupakan undang-undang perkawinan nasional yang menganut asas monogami, begitu juga dengan seorang anggota kepolisian hanya boleh mempunyai istri satu. Namun demikian boleh memiliki istri lebih dari satu apabila memenuhi syarat-syarat. Metode dalam penelitian ini menggunakan metode penelitian deskriptif kualitatif dengan pendekatan yuridis normatif. Hasil penelitian ini adalah : Penanganan terhadap anggota Polisi yang melakukan pelanggaran kode etik anggota Kepolisian Indonesia atas status perkawinan di wilayah hukum Polda Jawa Tengah, misalnya oknum anggota melakukan kawin siri yaitu pertama adanya laporan, terus dilakukan penyelidikan, dan penyidikan untuk mengungkap kebenaran kasus tersebut, setelah kabar itu benar, maka dilakukan pemeriksaan perkara yang menghadirkan barang bukti dan para saksi maupun korban, setelah dikumpulkan buktibukti dan keterangan dari para saksi maupun korban, maka dibuat berita acara pemeriksaan dan dibuat berita acara pemeriksaaan (BAP) dan dilakukan persidangan terhadap terduga pelanggar dan para saksi maupun korban, serta dijatuhi hukuman kalau benar bersalah sesuai aturan yang berlaku. Perkap No 6 Tahun 2018 sebagai aturan yang ideal dalam penanganan tentang perkawinan bagi anggota Polri, Peraturan Kapolri Nomor 14 Tahun 2011 tentang Kode Etik Profesi Kepolisian Negara Republik Indonesia, Pemerintah Republik Indonesia Nomor 2 Tahun 2003 tentang Disiplin anggota Polri dan merujuk pada Undang-Undang No 2 Tahun 2002 Tentang Kepolisian Republik Indonesia.
\end{abstract}

Kata kunci : Pelanggaran; Kode Etik; Anggota Kepolisian; Perkawinan 


\title{
HANDLING OF MEMBER CODE BREACHES POLICE ON MARRIAGE STATUS
}

\begin{abstract}
The purpose of this study is to examine how the handling of the code of ethics for members of the Police in the jurisdiction of the Central Java Regional Police for marital status and how to handle the ideal repositioning of the code of ethics for members of the Police in the jurisdiction of the Central Java Regional Police for their marital status. Law Number 1 of 1974 which is a national marriage law which adheres to the principle of monogamy, likewise a member of the Police may only have one wife. However, it is permissible to have more than one wife if they meet the requirements. The method in this study used a qualitative descriptive research method with a normative juridical approach.The results of this study are: The handling of police officers who violate the code of ethics of members of the Indonesian Police for their marital status in the jurisdiction of the Central Java Regional Police, for example an individual member commits a siri marriage, namely, the first is a report, continuing investigations, and investigations to reveal the truth of the case, After the news is true, an examination of cases presenting evidence and witnesses and victims is carried out, after evidence and statements are collected from witnesses and victims, an examination report is made and an examination report (BAP) is made and a trial is conducted for the suspect. offenders and witnesses and victims, and will be sentenced if guilty is true in accordance with the applicable rules. Perkap No. 6 of 2018 as an ideal rule in handling marriage for members of the National Police, Regulation of the Chief of Police Number 14 of 2011 concerning the Professional Code of Ethics for the State Police of the Republic of Indonesia, Government of the Republic of Indonesia Number 2 of 2003 concerning Discipline for members of the National Police and referring to Law No. 2 of 2002 concerning the Police of the Republic of Indonesia.
\end{abstract}

Keywords: Handling; Code of Ethics; Police Members, Marriage 


\section{A. PENDAHULUAN}

Perkawinan merupakan suatu peristiwa yang sakral dan sangat penting dalam kehidupan keluarga. Dalam praktek, perkawinan tidak hanya menyangkut masalah pribadi dari para pihak yang menjalankan perkawinan, akan tetapi hal ini juga menyangkut masalah keluarga, kerabat bahkan masyarakat. Karena perkawinan sebagai langkah awal dalam membentuk suatu keluarga kecil yang bahagia dan sejahtera lahir dan batin sesuai yang diamanatkan oleh UUD $1945 .^{1}$

Sesuai dengan landasan falsafah Pancasila dan Undang-Undang Dasar 1945, maka undang-undang perkawinan disalah satu pihak harus mewujudkan prinsipprinsip yang terkandung dalam Pancasila dan UUD $1945 .^{2}$ Perkawinan dapat meminimalisir perbuatan tercela, seperti keinginan untuk berzina di luar nikah, sedangkan bagi manusia yang sudah menikah dapat menentramkan jiwa dan dipandang oleh masyarakat secara umum bahwa ia sudah sempurna dan terpelihara dari perbuatan mungkar. Hal ini tercantum dalam Firman Allah SWT dalam surat Al Furqan ayat $74 .{ }^{3}$ Dengan adanya perkawinan rumah tangga dapat ditegakkan dan dibina sesuai dengan norma agama dan tata kehidupan bermasyarakat. ${ }^{4}$

Selanjutnya dalam Pasal 3 ayat (1) disebutkan bahwa pada dasarnya dalam suatu perkawinan seorang pria hanya diperbolehkan mempunyai seorang istri, dan sebaliknya seorang wanita hanya mempunyai seorang suami. Dari Pasal tersebut diatas dapat ditarik kesimpulan bahwa Undang-Undang Nomor 1 Tahun 1974 menganut suatu asas perkawinan monogami, tetapi dalam Undang-Undang perkawinan juga memberikan perkecualian bagi orang-orang tertentu yang menurut peraturan agama yang dianutnya memang diijinkan untuk menikah dari satu itu walau dengan syarat-syarat yang cukup berat. Poligami menurut agama Islam dapat

${ }^{1}$ Budi Prasetyo, Perspektif Undang-Undang Perkawinan Terhadap Perkawinan di Bawah Umur, Jurnal Ilmiah Serat Acitya, 6(1), 2017, hal. 135.

${ }^{2}$ Novita Lestari, Problematika Hukum Perkawinan di Indonesia, Jurnal Ilmiah Mizani 4 (1), 2017, hal. 43. http://dx.doi.org/10.29300/mzn.v4i1.1009

${ }^{3}$ Riyandi S, Syarat Adanya Persetujuan Istri Untuk Berpoligami (Analisis Ushul Fikih Syaffiyah Terhadap Undang-Undang Perkawinan No 1 Tahnu 1974), Jurnal Ilmiah Islam Futura 15(1), Agustus 2015. http://dx.doi.org/10.22373/jiif.v15i1.561

${ }^{4}$ Safrudin Yudowibowo, Tinjauan Hukum Perkawinan di Indonesia Terhadap Konsep Kafa'ah Dalam Hukum Perkawinan Islam, Fakultas Hukum Universitas Sebelas Maret, Jurnal Hukum 1(2), 2012 hal. 99. https://doi.org/10.20961/yustisia.v1i2.10632 
e-ISSN : 2621-4105

diketahui dalam Kitab Suci Al-Qur'an Surat An Nisa ayat 3 yang artinya : "Dan jika kamu takut tidak akan dapat berlaku adil terhadap (hak-hak) perempuan yang yatim (bilamana kami mengawininya), maka kawinilah wanita-wanita lain yang kamu senangi, dua, tiga atau empat. Kemudian jika kamu takut tidak berlaku adil, maka kawinilah seorang saja, atau budak-budak yang kamu miliki yang demikian itu adalah lebih dekat kepada tidak berbuat aniaya" ${ }^{5}$

Praktek perkawinan poligami yang ada di tengah-tengah masyarakat terdapat banyak ragam dan bentuk dalam pelaksanaanya, ada pernikahan poligami yang memang telah mendapatkan izin dari Pengadilan Agama resmi melalui prosedur yang ditetapkan oleh Undang-undang, namun tidak sedikit pula praktek perkawinan poligami yang dilakukan secara sirri (pernikahan poligami yang tidak memperoleh izin dari Pengadilan Agama sehingga tidak dicatatkan), trend pernikahan poligami sirri ini dewasa ini telah banyak kita jumpai di antaranya pernikahan poligami sirri Moerdiono, Syekh Pujiono, bahkan poligami sirri mantan Bupati Garut Aceng Fikri. $^{6}$

Seorang anggota Kepolisian merupakan abdi Negara, yang mempunyai tugas menjaga keamanan dan ketertiban Negara, maka untuk menjalankan tugasnya itu dimulai menjaga keutuhan dan keharmonisan rumah tangganya. Apabila rumah tangga harmonis, jelas untuk menjalankan tugas dan fungsinya sebagai aparat penegak hukum serta menjaga keamanan dan ketertiban Negara bisa berjalan dengan baik. Anggota Kepolisian hanya boleh mempunyai istri satu atau menganut monogami.

Penelitian tentang pelanggaran kode etik anggota POLRI telah dilakukan oleh Fitra Octoriny (2019) yang berjudul "Penerapan Hukuman Disiplin Terhadap Anggota Kepolisian Negara Republik Indonesia Yang Melakukan Nikah Siri Oleh Provos Di Polda Sumbar”. Dalam penelitiannya tersebut penerapan sanksi telah berjalan sebagaimana mestinya pemberian sanksi disiplin terhadap pelaku telah

${ }^{5}$ Bachtiar Surin, Terjemahan dan Tafsir Al Qur'an, hal 115

${ }^{6}$ Ahmad Cholid Fauzi, Kedudukan Hukum Itsbat Nikah Poligami Sirri, Jurnal USM Law Review 1(1), 2017, hal 96. http://dx.doi.org/10.26623/julr.v1i1.2234 
e-ISSN : 2621-4105

menimbulkan efek jera dan sebagai contoh bagi anggota Polda Sumbar. ${ }^{7}$ Penelitian ini mengkaji bagaimana penanganan anggota POLRI yang melakukan pelanggaran kode etik status perkawinan dengan melakukan nikah sirri di lingkunga Polda Sumatra Barat.

Penelitian yang dilakukan oleh Shinta Dewi Rismawati (2017) yang berjudul "Konstruksi Hukum Perkawinan Poligami di Indonesia (Prespektif Hukum Feminis)" dari hasil penelitian tersebut menyimpulkan bahwa konstruksi hukum eksiting tentang pengaturan poligami diatur dalam UU No 1 Tahun 1974 tentang Perkawinan ternyata bersifat ambigius, mendua, abu-abu ternyata memicu ragam budaya hukum dalam pelaksanannya. Kondisi ini justru melanggengkan ketidakpastian dalam hukum perkawinan itu sendiri.Sementara paradigm partiarkhi konvensional, UU Perkawinan juga disinyalir justru melegitimasi seksualitas suami untuk berpoligami dengan menempatkan steorotif pada perempuan sebagai ordinat pijakannya. Ketidakberdayaan perempuan secara fisik (sakit dan tidak bisa memberikan keturunan-mandul) serta psikis (sakit jiwa) menjadi alasan yang dibenarkan oleh hukum bagi suami untuk menikah lagi. ${ }^{8}$ Penelitianini tidak secara spesifik mengakaji tentang pelanggaran kode etik status perkawianan anggota POLRI.

Sedangkan penelitian oleh Dwi Oknerison (2014) tentang penegakan kode etik profesi terhadap perilaku anggota kepolisian dalam menangani perkara pidana, lebih fokus mengkaji bagaimana peran lembaga Kepolisian RI dalam penanganan perkara pidana dan bagaimana jenis pelanggaran kode etik profesi Kepolisian RI dan penegakan hukumnya. ${ }^{9}$ Penelitian ini tidak mengkaji secara khusus pelanggaran kode etik anggota POLRI atas status perkawinan. Penelitian ini hanya fokus mengkaji tentang penegakan kode etik profesi dalam penanganan perkara pidana.

${ }^{7}$ Fitra Octoriny, Penerapan Hukuman Disiplin Terhadap Anggota Kepolisian Negara Republik Indonesia Yang Melakukan Nikah Siri Oleh Provos Di Polda Sumbar, Jurnal Normative 7(1), 2017.

https://doi.org/10.31317/normative\%20jurnal\%20ilmah\%20hukum.v7i1\%20April

${ }^{8}$ Shinta Dewi Rismawati, Konstruksi Hukum Perkawinan Poligami di Indonesia (Prespektif Hukum Feminis), Jurnal Mawazah 9(2), 2017. https://doi.org/10.28918/muwazah.v9i2.1124

${ }^{9}$ Dwi Oknerison, Penegakan Kode Etik Profesi Terhadap Perilaku Anggota Kepolisian Dalam Menangani Perkara, Jurnal Lex et Societatis 2(6), 2014. 
Penelitian ini melengkapi penelitian sebelumnya yang banyak membahas tentang pelanggaran kode etik pada status perkawinan anggota kepolisian. Perbedaan penelitian ini dari penelitian sebelumnya adalah bagaimana dalam penelitian ini meneliti tentang penanganan pelanggaran kode etik status perkawinan anggota POLRI di lingkup Polda Jawa Tengah. Dari hal tersebut dapat menjelaskan bahwa penelitian ini berbeda dengan penelitian sebelumnya. Tujuan penelitian ini adalah untuk mengkaji bagaimana penanganan pelanggaran kode etik anggota Kepolisian di wilayah hukum Polda Jawa Tengah atas status perkawinan penanganan ideal pelanggaran kode etik anggota Kepolisian di wilayah hukum Polda Jawa Tengah atas status perkawinannya.

\section{B. Perumusan Masalah}

Dalam penelitian ini rumusan masalah dirumuskan sebagai berikut :

1. Bagaimana penanganan pelanggaran kode etik anggota Kepolisian di wilayah hukum Polda Jawa Tengah atas status perkawinan?

2. Bagaimana penanganan ideal pelanggaran kode etik anggota Kepolisian di wilayah hukum Polda Jawa Tengah atas status perkawinannya?

\section{Metode Penelitian}

Metode penelitian yang dipakai yaitu yuridis normatif. Menurut Soerjono Soekanto pendekatan yuridis normatif yaitu penelitian hukum yang dilakukan dengan cara meneliti bahan pustaka atau data sekunder sebagai bahan dasar untuk diteliti dengan cara mengadakan penelusuran terhadap peraturan-peraturan dan literatur-literatur yang berkaitan dengan permasalahan yang diteliti ${ }^{10}$.

Sifat penelitian ini disesuaikan dengan masalah yang dipergunakan penelitian yang bersifat deskriptif analitis, yaitu menggambarkan yang jelas, rinci dan sistematis tentang objek yang diteliti. Analitis artinya data yang diperoleh akan dianalisis untuk pemecahan terhadap permasalahan sesuai dengan ketentuan hukum yang berlaku. Hal utama yang ingin didiskripsikan adalah Penanganan Pelanggaran Kode Etik Anggota Kepolisian Republik Indonesia Atas Status Perkawinan.

Sumber data yang dipergunakan dalam penelitian ini adalah :

\footnotetext{
${ }^{10}$ Soerjono Soekanto \& Sri Mamudji, Penelitian Hukum Normatif (Suatu Tinjauan Singkat), Rajawali Pers, Jakarta, 2001, hlm 13
} 
e-ISSN : 2621-4105

1. Sumber data utama, yaitu data sekunder, dimana data ini diperoleh dari penelitian kepustakaan dan didukung atau dilengkapi dengan data-data yang diperoleh dari penelitian lapangan.

2. Sumber data pendukung adalah data primer, yaitu data yang diperoleh dari penelitian lapangan.

\section{PEMBAHASAN}

\section{Penanganan Pelanggaran Kode Etik Anggota Kepolisian Di Wilayah Hukum Polda Jateng Atas Status Perkawinan}

Penanganan pelanggaran kode etik yang dilakukan oleh oknum Kepolisian di lingkungan Polda Jawa Tengah yaitu tentang status perkawinan. Peraturan yang mengatur tata cara pengajuan perkawinan, perceraian dan rujuk bagi Pagawai Negeri pada Kepolisian Negara Republik Indonesia yaitu No 9 tahun 2010.

Terhadap persoalan-persoalan tersebut seorang polisi dapat dikenakan sanksi karena termasuk melakukan tindakan pelanggaran kode etik kepolisian. Dasar hukumnya bisa dilihat dalam Peraturan Pemerintah RI Nomor 1 Tahun 2003 tentang pemberhentian anggota Kepolisian negara. Undang-undang Nomor 2 Tahun 2002 tentang Kepolisian Negara Republik Indonesia, dan Keputusan Kapolri Tahun 2003 tentang Kode Etik Profesi Kepolisian. Selain itu ketentuan mengenai Kode Etik Profesi Polri sebagaimana diatur dalam peraturan Kapolri Nomor 14 Tahun 2011. ${ }^{9}$

Pasal 1 menguraikan tentang Kepolisian Negara Republik Indonesia yang selanjutnya disingkat Polri adalah alat negara yang berperan dalam memelihara keamanan, ketertibanmasyarakat, menegakkan hukum, serta memberikan perlindungan, pengayoman, dan pelayanan kepada masyarakat dalam rangkaterpeliharanya keamanan dalam negeri, merupakan penjelasan dalam Pasal 1. Pasal 2, Pegawai Negeri pada Polri adalah anggota Polri dan Pegawai Negeri Sipil (PNS) pada Polri.

Ikatan lahir batin antara seorang pria dengan seorangwanita sebagai suamiistri dengan tujuan membentuk keluarga (rumahtangga) yang bahagia dan kekal

9 Nozel Saparingka, Penyelesaian Pelanggaran Kode Etik Kepolisian Berpotensi Pidana,Jurnal, Universitas Atma Jaya Yogyakarta, Jurnal, Fakultas Hukum, 2016, hlm. 1 
berdasarkan Ketuhanan Yang Maha Esa, pengertian perkawinan. Sedangkan pengertian perceraian adalah putusnya hubungan perkawinan antara suami istri berdasarkan keputusan Pengadilan Agama atau Pengadilan Negeri, penjelasan dalam Pasal 1 ayat (4).

Peraturan kepolisian Negara Republik Indonesia memiliki prinsip legalitas, akuntabilitas,transparansi dan keadilan. Adapun penjelasan prinsip-prinsip tersebut yaitu sebagai berikut ;

a. legalitas, yaitu setiap proses pengajuan perkawinan, perceraian, dan rujukdilakukan sesuai dengan ketentuan peraturan perundang-undangan gunamenjamin hak dan kewajiban;

b. akuntabilitas, yaitu setiap proses pengajuan perkawinan, perceraian, danrujuk dilakukan secara prosedural dan dapat dipertanggungjawabkan;

c. transparansi, yaitu setiap proses pengajuan perkawinan, perceraian, danrujuk dilakukan secara terbuka;

d. keadilan, yaitu setiap proses pengajuan perkawinan, perceraian, dan rujukdilakukan secara adil tanpa diskriminasi; dan

Tujuan Peraturan yang mengatur tata cara pengajuan perkawinan, perceraian dan rujuk bagi Pagawai Negeri Pada Kepolisian Negara Republik Indonesia yaitu No 9 tahun 2010 ini adalah :

a. Sebagai pedoman dalam pengajuan izin kawin, cerai dan rujuk bagi pegawai negeri pada Polri

b. Menjamin terwujudnya tertib administrasi perkawinan, perceraian dan rujuk di lingkungan Polri

Peraturan No 9 tahun 2010 memuat tentang atau berisi tentang :

a. Persyaratan pengajuan perkawinan, perceraian dan rujuk

b. Pejabat yang berwenang memberikan izin kawin, cerai dan rujuk

c. Tata cara pengajuan izin kawin, cerai dan rujuk

b) Penanganan terhadap Anggota Polisi yang melakukan pelanggaran kode etik anggota Kepolisian Indonesia atas status perkawinan di wilayah hukum Polda Jawa Tengah, misalnya oknum anggota melakukan kawin siri yaitu pertama adanya laporan, terus dilakukan penyelidikan, dan penyidikan untuk 
mengungkap kebenaran kasus tersebut, setelah kabar itu benar, maka dilakukan pemeriksaan perkara yang menghadirkan barang bukti dan para saksi maupun korban, setelah dikumpulkan bukti-bukti dan keterangan dari para saksi maupun korban, maka dibuat berita acara pemeriksaan dan dibuat berita acara pemeriksaaan (BAP) dan dilakukan persidangan terhadap terduga pelanggar dan para saksi maupun korban, serta dijatuhi hukuman kalau benar bersalah sesuai aturan yang berlaku.

Mengenai oknum Kepolisian yang akan melakukan perkawinan poligami tersebut tanpa ijin atau tidak melalui prosedur yang ada misalnya dengan kawin siri atau punya wanita simpanan, padahal kawin siri menurut hukum dianggap tidak sah karena tidak memenuhi syarat-syarat sahnya perkawinan. Dan apabila oknum Kepolisian tetap melakukan poligami secara diam-diam tanpa ada ijin dari pihakpihak lain, dan apabila sampai dikaruniai anak maka anak tersebut tetap dianggap sah tetapi tidak mempunyai kekuatan hukum. Dan mengenai soal gaji istri kedua tidak berhak untuk mendapat gaji karena perkawinan dilakukan dengan cara diamdiam dan tidak sah menurut hukum.

Sedangkan akibat hukum jika oknum Kepolisian yang melakukan perkawinan poligami tanpa ijin tersebut ketahuan baik istri atau pihak lain dan dilaporkan pada atasannya maka oknum Kepolisian tersebut akan dikenai sanksi sesuai dengan aturan yang berlaku bagi setiap anggota Polri yang dituangkan dalam kode etik Kepolisian. Kode etik profesi Kepolisian Negara Republik Indonesia pada dasarnya merupakan pedoman bagi pengemban fungsi kepolisian lainnya dalam melaksanakan tugas sesuai dengan peraturan perundang-undangan yang berlaku di lingkungannya, oleh karena itu kode etik profesi memiliki peranan penting dalam mewujudkan polisi yang professional. ${ }^{8}$

\section{Penanganan Ideal Atas Reposisi Pelanggaran Kode Etik Anggota Kepolisian Di Wilayah Hukum Polda Jawa Tengah Atas Status Perkawinannya}

Apabila anggota Kepolisian yang melanggar mempunyai istri/suami lebih dari satu dikenakan Peraturan Kapolri Nomor 14 Tahun 2011 tentang Kode Etik Profesi

8 Petrus Kanisius Noven Manalu, Fungsi Kode Etik Profesi Polisi Dalam Rangka Meningkatkan Profesionalitas Kinerjanya, Uiversitas Atma Jaya Yogyakarta, Jurnal, Fakultas Hukum, 2014, hlm 1 
e-ISSN : 2621-4105

Kepolisian Negara Republik Indonesia. Apabila anggota Kepolisian tetap melakukan poligami secara diam-diam tanpa ada ijin dari pihak-pihak lain, dan apabila sampai dikaruniai anak maka anak tersebut tetap dianggap sah tetapi tidak mempunyai kekuatan hukum. Dan mengenai soal gaji istri kedua tidak berhak untuk mendapat gaji karena perkawinan dilakukan dengan cara diam-diam dan tidak sah menurut hukum.

Sedangkan akibat hukum jika anggota Kepolisian yang melakukan perkawinan poligami tanpa ijin tersebut ketahuan baik istri atau pihak lain dan dilaporkan pada atasannya maka anggota Kepolisian tersebut akan dikenai sanksi yaitu berupa pemberhentian dengan hormat tidak atas permintaan sendiri sebagai anggota Kepolisian hal ini diatur dalam peraturan kode etik Kepolisian.

Karena anggota Kepolisian merupakan abdi negara dan harus memberi contoh yang baik pada bawahan atau masyarakat maka kepada anggota Kepolisian dibebankan ketentuan disiplin yang tinggi untuk melakukan perkawinan dan perceraian. Dan apabila anggota Kepolisian melakukan perkawinan atau perceraian harus mendapat ijin dari atasan dan apabila sampai melanggar ketentuan-ketentuan yang ada maka sudah sepatutnya kalau dikenai sanksi karena anggota Kepolisian merupakan panutan orang yang ada dibawahnya.

Berdasarkan pembahasan diatas bahwa penanganan terhadap pelanggaran kode etik profesi Polri yang terjadi di wilayah hukum Polda Jawa Tengah adalah kasus WIL atau kawin siri, merujuk pada Peraturan Kepolisian Negara Republik Indonesia No 6 Tahun 2018 Tentang perkawinan, Peraturan Kapolri Nomor 14 Tahun 2011 tentang Kode Etik Profesi Kepolisian Negara Republik Indonesia, Pemerintah Republik Indonesia Nomor 2 Tahun 2003 tentang Disiplin anggota Polri dan merujuk pada Undang-Undang No 2 Tahun 2002 Tentang Kepolisian Republik Indonesia.

Adapun tahap penanganan yang ideal terhadap anggota polisi yang melakukan pelanggaran kode etik profesi tentang status perkawianan adalah:

a) Anggota yang diduga melakukan perbuatan yang melanggar kode etik maka dilakukan pennyelidikan, dan penyidikan. 
b) Setelah itu dilakukan pemeriksaan perkara yang menghadirkan barang bukti dan para saksi maupun korban.

c) Setelah dikumpulkan bukti-bukti dan keterangan dari para saksi maupun korban, maka dibuat berita acara pemeriksaan dan dibuat berita acara pemeriksaaan (BAP).

d) Berita acara pemeriksaan (BAP) ini kemudian disampaikan kepada Komisi Kode Etik Profesi (KKEP) untuk ditindaklanjuti.

e) Dilakukan persidangan terhadap terduga pelanggar dan para saksi maupun korban.

f) Setelah dilakukan persidangan maka Komisi Kode Etik Profesi memutuskan perkara dengan memberikan sanksi sesuai peraturan perundang-undangan yang berlaku.

g) Setelah diputuskan maka tersangka/terpidana menerima dan menjalani sanksi putusan dengan hukuman terberat adalah pemberhentian tidak dengan hormat (PTDH) atau dengan kata lain anggota dikeluarkan dari Instansi Kepolisian Republik Indonesia tanpa mendapatkan gaji maupun pesangon.

\section{E. PENUTUP}

Penanganan terhadap Anggota Polisi yang melakukan pelanggaran kode etik anggota Kepolisian Indonesia atas status perkawinan di wilayah hukum Polda Jawa Tengah, misalnya oknum anggota melakukan kawin siri yaitu pertama adanya laporan, terus dilakukan penyelidikan, dan penyidikan untuk mengungkap kebenaran kasus tersebut, setelah kabar itu benar, maka dilakukan pemeriksaan perkara yang menghadirkan barang bukti dan para saksi maupun korban, setelah dikumpulkan bukti-bukti dan keterangan dari para saksi maupun korban, maka dibuat berita acara pemeriksaan dan dibuat berita acara pemeriksaaan (BAP) dan dilakukan persidangan terhadap terduga pelanggar dan para saksi maupun korban, serta dijatuhi hukuman kalau benar bersalah sesuai aturan yang berlaku. Penanganan yang ideal merujuk pada Peraturan Kepolisian Negara Republik Indonesia No 6 Tahun 2018 Tentang perkawinan, Peraturan Kapolri Nomor 14 Tahun 2011 tentang Kode Etik Profesi Kepolisian Negara Republik Indonesia, Pemerintah Republik 
e-ISSN : 2621-4105

Indonesia Nomor 2 Tahun 2003 tentang Disiplin anggota Polri dan merujuk pada

Undang-Undang No 2 Tahun 2002 Tentang Kepolisian Republik Indonesia.

\section{DAFTAR PUSTAKA}

\section{Buku}

Bachtiar Surin, Terjemahan dan Tafsir Al Qur'an

Lexi J. Moleong, 2007, Metode Penelitian Kualitatif, Remaja Rosdakarya, Bandung

Soerjono Soekanto \& Sri Mamudji, Penelitian Hukum Normatif (Suatu Tinjauan

Singkat), Rajawali Pers, Jakarta, 2001.

\section{Jurnal}

Ahmad Cholid Fauzi, Kedudukan Hukum Itsbat Nikah Poligami Sirri, Jurnal USM Law Review 1(1), 2017. http://dx.doi.org/10.26623/julr.v1i1.2234

Budi Prasetyo, Perspektif Undang-Undang Perkawinan Terhadap Perkawinan di Bawah Umur, Jurnal Ilmiah Serat Acitya 6(1), 2017.

Dwi Oknerison, Penegakan Kode Etik Profesi Terhadap Perilaku Anggota Kepolisian Dalam Menangani Perkara, Jurnal Lex et Societatis 2(6), 2014.

Fitra Octoriny, Penerapan Hukuman Disiplin Terhadap Anggota Kepolisian Negara Republik Indonesia Yang Melakukan Nikah Siri Oleh Provos Di Polda Sumbar, Jurnal Normative 7 (1), 2017.

https://doi.org/10.31317/normative\%20jurnal\%20ilmah\%20hukum.v7i1\%20Ap ril

Novita Lestari, Problematika Hukum Perkawinan di Indonesia, Jurnal Ilmiah Mizani 4 (1), 2017. http://dx.doi.org/10.29300/mzn.v4i1.1009

Nozel Saparingka, Penyelesaian Pelanggaran Kode Etik Kepolisian Berpotensi Pidana,Jurnal, Universitas Atma Jaya Yogyakarta, Jurnal, Fakultas Hukum, 2016.

Riyandi S, Syarat Adanya Persetujuan Istri Untuk Berpoligami (Analisis Ushul Fikih Syaffiyah Terhadap Undang-Undang Perkawinan No 1 Tahnu 1974), Jurnal Ilmiah Islam Futura 15 (1), Agustus 2015.

http://dx.doi.org/10.22373/jiif.v15i1.561

Safrudin Yudowibowo, Tinjauan Hukum Perkawinan di Indonesia Terhadap Konsep Kafa'ah Dalam Hukum Perkawinan Islam, Fakultas Hukum Universitas Sebelas Maret, Jurnal Hukum Yustisia 1 (2), 2012. https://doi.org/10.20961/yustisia.v1i2.10632

Shinta Dewi Rismawati, Konstruksi Hukum Perkawinan Poligami di Indonesia (Prespektif Hukum Feminis), Jurnal Mawazah 9 (2), 2017. https://doi.org/10.28918/muwazah.v9i2.1124

Petrus Kanisius Noven Manalu, Fungsi Kode Etik Profesi Polisi Dalam Rangka Meningkatkan Profesionalitas Kinerjanya, Uiversitas Atma Jaya Yogyakarta, Jurnal Fakultas Hukum, 2014. 
e-ISSN : 2621-4105

\section{Undang-Undang dan Peraturan}

Undang-Undang No 1 Tahun 1974 Tentang Perkawinan

Undang-Undang No 2 Tahun 2002 Tentang Kepolisian Republik Indonesia 